\title{
El asalto al Olimpo: La Gigantomaquia
}

\author{
María Isabel RODRÍGUEZ LÓPEZ \\ Universidad Complutense de Madrid
}

RESUMEN: La Gigantomaquia ha sido un asunto predilecto de las artes plásticas; por ser el más elevado de los temas épicos ha sido recreado desde el arte griego del período arcaico hasta la Edad Contemporánea. Pinturas, esculturas y otras artes han evocado esta contienda entre dioses y hombres, cuyo significado, adquirió diversos tintes a lo largo de la Historia, en la mayoría de los casos con sentido propagandístico o alegórico. Este trabajo ofrece un panorama iconográfico de gran alcance temporal, con el que hemos pretendido reflexionar sobre el tema, atendiendo a fórmulas ideológicas, soluciones plásticas y medios expresivos.

Palabras clave: Iconografía Clásica, Mitología Clásica, gigantes, Gigantomaquia, dioses olímpicos.

RIASSUNTO: La Gigantomachia è stato uno degli argomenti prediletti dalle Arti Plastiche, il più elevato tra i temi epici, e per questo ricreato e rappresentato sin dal periodo arcaico, del arte greca, fino ai giorni odierni. Pitture, sculture e altre manifestazioni artistiche hanno evocato questa contenda tra gli dei e gli uomini, il cui significato, acquistò diverse vesti lungo la Storia, la maggior parte delle volte con un marcato senso propagandistico o allegorico. Questo lavoro offre un panorama iconografico di grande portata temporale, attraverso il quale abbiamo voluto riflettere su questo tema, dando spazio alle formule ideologiche, soluzioni plastiche e mezzi espressivi.

Parola chiave: Iconografia Classica, Mitologia Classica, Giganti, Gigantomachia, Dei olimpici.

\section{EL MITO Y SUS FUENTES.}

De acuerdo con Homero ${ }^{1}$, los Gigantes fueron una raza de hombres salvajes, gobernados por Eurimedonte que habitaban en la isla de Thrinacia, en el lejano oeste y que fueron exterminados por su insolencia hacia los dioses. Pertenecen, por tanto, a una tribu ancestral que fue destruida por su soberbia, y no por un combate, que no se cita en los poemas homéricos. La versión más difundida sobre su origen la da

\footnotetext{
${ }^{1}$ HOMERO, Odisea, VII, 59, 206.
}

Hesíodo $^{2}$, quien les considera seres divinos, nacidos de la sangre vertida en el seno de la tierra, Gea, cuando Urano fue mutilado por Crono. De ellos se dice que son seres enormes, de armaduras lustrosas e ingentes lanzas.

Según Píndaro ${ }^{3}$, los gigantes nacieron en los campos Flegreos, en Sicilia, Campania o en Arcadia, y según otras fuentes (Apolodoro, Pausanias, Píndaro o Es-

\footnotetext{
${ }^{2}$ Hesíodo, Teogonía, 183 y ss.

${ }^{3}$ PíndARO, Nemea, I, 67.
} 
trabón), en Palene (Tracia). Homero y varios escritores tardíos los sitúan en zonas volcánicas, por lo que parece probable que el origen de la historia de los gigantes esté relacionado con una explicación sobrenatural de determinados fenómenos físicos de la naturaleza, asociados con fenómenos volcánicos.

La literatura antigua insiste en el gran tamaño de sus cuerpos y en su invencible poder ${ }^{4}$. Ovidio ${ }^{5}$ los describe como monstruos furiosos que intentaron escalar el Olimpo y sobre los que recayó la cólera de Zeus. Algunos autores hablan de sus extremidades serpentiformes, de su cabellera formada por ofidios y de sus numerosas manos $^{6}$. Las descripciones literarias hacen de ellos seres formidables, de invencible fuerza y aspecto terrorífico. Sus nombres están en relación con su naturaleza y evocan fuerza, bravura, celeridad, impetuosidad, salvajismo, aspectos que definen su terrible personalidad ${ }^{7}$.

La Gigantomaquia es un mito en pleno sentido del término, ya que su desarrollo afecta a un cambio en el orden universal $^{8}$. Tras este episodio comenzaba una nueva era para la humanidad, regida por los hijos de Crono y Rea, que tras haberse repartido el dominio del Universo establecieron, como es bien sabido, su residencia en el Olimpo. La primera referencia textual

\section{-}

${ }^{4}$ Diodoro Sículo, Biblioteca Histórica, IV, 21, 5; APOLODORO, Biblioteca Mitológica, I, 34.

${ }^{5}$ Ovidio, Metamorfosis, I.

${ }^{6}$ NONNUS, Dionysiaca, 1,$18 ; 25,85$ y ss. 25,206 y ss; 48,6 .

${ }^{7}$ F. VIAN, La Guerre des géants. Le mythe avant l'epoque hellénistique, París, 1952, p.227. Para el tratamiento general del tema véase también F. VIAN, Répertoire des Gigantomachies figurées dans l'art grec et romaine, París, 1951 y E KUHNER, «Die Giganten in der Kunst», en Roscher, Lexicon, II, 1653-1673, 1965.

${ }^{8}$ P. GRIMAL, Diccionario de Mitología griega y romana, Barcelona, 1984 [1 $1^{a}$ ed. París, 1951] (Introducción, XV y ss.). al combate la ofrece Píndaro (518-430 a.C. ¿?) en una de sus Odas Nemeas 9 .

Apolodoro es el mitógrafo que nos brinda la versión más amplia y detallada de la contienda en su Biblioteca Mitológica ${ }^{10}$. Dicho texto narra cómo Gea, uniéndose a Urano concibe a los Gigantes, seres "insuperables por la magnitud de sus cuerpos e invencibles por su potencia física", provistos de espesa cabellera y extremidades de dragón. Señala el citado autor que las tradiciones con respecto a su nacimiento son diversas, ya que según unos habían nacido en Flegra, mientras que otras versiones sitúan el lugar del alumbramiento en Palene. Sea como fuere, estos invencibles y coléricos seres "arrojaban contra el cielo rocas y encinas ardientes". De todos ellos, Porfirio y Alcioneo eran los más fuertes, inmortal el segundo mientras permaneciera en contacto con la tierra madre. Sigue Apolodoro relatando que los dioses conocían un vaticinio según el cual los gigantes no perecerían si un mortal no combatía junto a ellos y que Gea intentó evitarlo fabricando un brebaje, destruido finalmente por Zeus. Fue el padre de los dioses quien llamó a Heracles para que ayudara a los Olímpicos. Iniciada la liza, el héroe disparó sus flechas contra Alcioneo, que recobraba el aliento y el vigor cada vez que caía a la tierra, hasta que por recomendación de la astuta Atenea, lo arrastró lejos de Palene para poder vencerlo. La suerte de Porfirio fue bien distinta: se enfrentó a Hera, y sintiendo por ella un gran deseo amoroso trató de arrancarle el peplo para violarla; la diosa pidió ayuda y el gigante fue exterminado por Heracles y Zeus que acudieron en su auxilio. El texto nos informa, también, de cómo Apolo atravesó con una de sus flechas el ojo izquierdo de Efialtes y Heracles el derecho; Dioniso exterminó a Éurito con el tirso, mientras

\footnotetext{
${ }^{9}$ PíndARO, Nemea, I, 67.

${ }^{10}$ ApOLODORO, Biblioteca Mitológica, I, 6,1-2.
} 
que Hécate mató a Clito con antorchas y Hefesto a Mimante "arrojando contra él hierros al rojo". Encélado intentó darse a la fuga, pero fue vencido por Atenea, que lanzó sobre él la isla de Sicilia. Polibotes fue perseguido por Posidón en el mar y vencido por el dios, quien arrojó contra el gigante el islote de Nísiro. El invisible Hermes, que vestía "el casco de Hades durante la batalla, mató a Hipólito y Ártemis a Gratión. Las Moiras que combatían con mazas de bronce, a Agrio y Toante; al resto los exterminó Zeus fulminándolos con rayos; a todos los agonizantes los alcanzó Heracles con sus flechas" ${ }^{11}$.

Algunos autores ${ }^{12}$ han señalado que el mito debió estar constituido en la Hélade en torno al siglo VIII a.C. y que la fuente de inspiración del mismo puede haber tenido su origen en algunos relatos muy antiguos, procedentes del mundo oriental, especialmente en el combate entre el dios hitita de la tempestad y el dragón Illuyanka, episodio en el que el dios solicita la ayuda de otros dioses y del héroe (un mortal) Hupashiya.

El escenario de tan crucial batalla se sitúa, generalmente, en la península de Palene, en Tracia, aunque una tradición local señala que el choque tuvo lugar en Arcadia, en las riberas del Alfeo ${ }^{13}$. Los adversarios más activos de los gigantes fueron Zeus y Atenea; Heracles ofreció su apoyo en la lucha, pero el héroe asiste al combate con prudencia, situado a cierta distancia y disparando sus flechas apostado en el carro de Zeus. A medida que la leyenda se fue enriqueciendo, intervienen en la lucha Dioniso, Ares, Hefesto, Afrodita, Eros, Posidón... y todos los olímpicos.

-

11 ApOLODORO, Biblioteca Mitológica, I, 6,1-2.

${ }^{12}$ C. Delgado LinACERO, «La Gigantomaquia, símbolo socio-político en la concepción de la polis griega», Espacio, Tiempo y Forma, Historia Antigua (12), 107-127, p.109.

${ }^{13}$ PAUSANIAS, Descripción de Grecia, VIII, 29,1.1.

\section{ICONOGRAFÍA}

En opinión de algunos especialistas ${ }^{14}$ la Gigantomaquia es un tema sublime, el más grande de la Épica, ya que en él se ensamblan para formar un todo, las historias de los dioses y las batallas. Con tales ingredientes, no es extraño que el asunto se convirtiera, desde el siglo VI a.C., en un motivo predilecto de los artistas griegos, que vieron en sus imágenes un medio efectivo para expresar, ideas relacionadas con la convivencia ciudadana, la religiosidad o los asuntos de la más alta política.

\section{GRECIA ARCAICA}

La Gigantomaquia comenzó a tomar forma en las artes plásticas a partir del 550 a.C., siendo ceramistas y escultores los encargados de plasmar el mito a través de sus iconos. Las más antiguas representaciones que han llegado hasta nosotros proceden de los repertorios ceramográficos áticos y corintios, que muestran, ya desde mediados del siglo VI a.C., diferentes momentos de la confrontación. Dichas imágenes son anteriores a las Nemeas de Píndaro, por lo que parece probable que pudiera haber existido otra referencia literaria griega que estimulara tan amplio florecimiento del tema en el arte arcaico. Delgado Linacero ha puesto de relieve una interesante relación entre las ideas y los valores predominantes en las poleis griegas del Arcaísmo con una posible lectura simbólica del tema que nos ocupa. Señala la citada autora que en este momento de formación de las ciudades, el ideal político de isonomía que ansiaba la moderación como virtud, la victoria de los olímpicos podría interpretarse como un nuevo orden. Gracias a ese orden, la razón se manifestaba en una sociedad, donde, a partir de este momento, habría de imponerse la

${ }^{14}$ D.C. INNES, «Gigantomachy and Natural Philosophy», The Classical Quarterly New Series, vol.21, n.1 (1979), pp. 165-171. 
descendencia patrilineal sobre el matriarcado $^{15}$.

Como es sabido, la ciudad de Atenas fue uno de los centros políticos más influyentes de aquel tiempo; allí se remodeló, en torno al 525 a.C., el "viejo templo" de la diosa Políada, en la Acrópolis. Dicho templo fue construido en piedra hacia el 625 a.C. y estuvo rodeado por un pórtico de columnas de madera. Sustituyó a otro santuario anterior, edificado éste sobre los restos de un palacio micénico. No parece casual que en la decoración de uno de sus frontones se representara una colosal Gigantomaquia, de la que hoy se conservan algunas figuras -en estado muy fragmentario- en el Museo de la Acrópolis ${ }^{16}$. Atenea, protectora de la ciudad y de sus enemigos, es una figura formidable, caracterizada como una Kore por su peinado e indumentaria, pero convenientemente armada con la égida; la diosa aparece en actitud dinámica y victoriosa, como Atenea Gigantophonos, mientras que sus oponentes desnudos y sin armamento, prácticamente abatidos, yacen heridos en la tierra. En el marco de la mentalidad ateniense del momento, y dada la sacralidad del emplazamiento del "viejo templo", el asunto se concebiría, probablemente, como tema propagandístico con el que ensalzar la superioridad intelectual y política de la ciudad de Atenas. Su diosa tutelar, hija de Metis (Prudencia) y de Zeus (padre de los dioses y garante del cumplimiento de la Justicia) aplasta con su inteligencia a los enemigos de la polis, incluso hasta los más brutales y terroríficos.

Por los mismos años se levantó, en el témenos del Santuario de Apolo en Delfos,

${ }^{15}$ C. Delgado Linacero, Op. Cit. p. 111.

16 M.B. MOORE, «The Central Group in the Gigantomachy of the Old Athena Temple on the Acropolis» American Journal of Archaeology, Vol. 99, n. 4 pp. 633-639, 1995. el Tesoro de los Sifnios ${ }^{17}$. El relieve continuo de su friso norte, en la Antigüedad animado por vivos colores, representa la confrontación entre los dioses y los gigantes y la lucha entre griegos y troyanos, programa iconográfico que no deja lugar a dudas sobre la intencionalidad política del asunto elegido $^{18}$. Las figuras de los rivales se mezclan en una compleja y hermosa sucesión de planos, que trasmiten el fragor de la batalla con notable dinamismo. Sin apenas armamento, los olímpicos hacen frente a los hijos de Gea que aparecen prácticamente ocultos tras la panoplia característica del hoplita griego (provistos de yelmo, coraza, grebas, escudo, espada y lanza), según los describe Hesíodo en la Teogonía. En el bando de los dioses pueden distinguirse, en virtud de sus fisonomías y atributos, a Apolo y Ártemis, Cibeles, Heracles y Atenea, mientras que los gigantes, seres genéricos, no se diferencian entre sí (fig.1). Como apuntó Vian, el asunto fue muy apreciado por los artistas y se representó también en el frontón del Tesoro de Megara, en Olimpia, en el frontón oeste del Templo de los Alcmeónidas, en el friso del Tesoro de Marsella y en el frontón occidental del Tesoro de los Atenienses, en Delfos ${ }^{19}$

-

17 L.V. WATROUS, «The Sculptural Program of the Siphnian Treasury at Delphi», American Journal of Archaeology, Vol. 86, n. 2, 1982, pp. 159-172; W. R. AGARD, «Notes on the Siphnian Treasury Frieze», American Journal of Archaeology, Vol. 42, n. 2, 1983, pp. 237-244; M. B. MOORE, «The Gigantomachy of the Siphnian Treasury : Reconstruction of the three Lacunae», Bulletin de correspondance hellénique. Supplément, Año 1977, Vol. 4, pp. 305-335.

${ }^{18}$ Como santuario panhelénico, Delfos constituía un escenario muy adecuado para la propaganda política, un escaparate de los ideales de la Hélade, que se reflejaban a través de las imágenes. Véase: R. T. NEER, «Framing the Gift: The Politics of the Siphnian Treasury at Delphi», Classical Antiquity, Vol. 20, n. 2, 2001, pp. 273-344.

${ }^{19}$ F. VIAN, Op. Cit., 1952, p. 115. 
Las metopas del llamado Templo $\mathrm{F}$ de Selinunte (Sicilia), consagrado a Atenea, estuvieron decoradas, asimismo, con una Gigantomaquia, cuyos restos se conservan hoy en el Museo Arqueológico de Palermo $^{20}$. Fechados hacia el 530-525 a.C., los relieves que han llegado hasta nosotros representan a Atenea combatiendo con Encélado y a Dioniso frente a otro gigante. Todas las obras citadas muestran a los gigantes como seres de fisonomía humana, en unos casos desnudos (aludiendo, como se ha señalado, a su primitivismo o bien para indicar que se trata de seres de estirpe divina) y en otras ocasiones ataviados como fuertes guerreros completamente guarnecidos por su armamento, en el que predomina el casco de tipo corintio.

Las representaciones pictóricas de los vasos cerámicos recrearon el asunto, desde mediados del siglo VI a.C., en composiciones colmadas de dinamismo. A modo de friso continuo, la narración mítica suele ocupar los "hombros" de las vasijas; los dioses portan escudos y lanzas y ostentan sus atributos de poder (tirso, tridente, rayo, caduceo...), mientras que sus adversarios aparecen, como ya se ha señalado, completamente protegidos y sosteniendo piedras o ramas de árboles -a modo de armas arrojadizas- en sus manos. El ejemplo más antiguo de los vasos pintados que han llegado hasta nosotros es un dinos de figuras negras firmado por Lydos, que fue dedicado en la Acrópolis ateniense. El vaso presenta un estado de conservación muy fragmentario y sin embargo, constituye uno de los ejemplos más significativos de la lucha entre dioses y gigantes del arcaísmo griego. Los trabajos de Francis Vian ${ }^{21}$ y de Mary B.

${ }^{20}$ M. SANTANGello, Selinunte, Roma, 1953; V. TUSA, La scultura in pietra di Selinunte, Palermo, 1984.

${ }^{21}$ F. VIAN, Op. Cit. (1952), pp. 95-101.
Moore $^{22}$ han propuesto una posible reconstrucción del conjunto, en virtud de los fragmentos conservados en el Museo de la Acrópolis $^{23}$. La batalla aparece ante nuestros ojos como el verdadero punto de partida para el desarrollo iconográfico del tema que abordamos; Hefesto, Afrodita, Dioniso, Hermes, Hera, Zeus, Atenea, Ares, Posidón y Heracles combaten frente a frente, contra sus enemigos, ataviados éstos últimos como hoplitas. Algunos gigantes yacen vencidos en el suelo, mientras que muchos de ellos permanecen todavía erguidos ante sus poderosos rivales.

En ocasiones, los vasos áticos se embellecen con episodios aislados de la contienda, en un intento de simplificación y evolución plástica, acaso influenciada por el estilo tendente al naturalismo iniciado por Exequias. El campo decorativo proporcionado por los recipientes cerámicos resultaba muy apto para la representación del enfrentamiento de parejas y el choque entre dos figuras proporcionaba un medio de experimentación con el que los pintores podían expresar la contraposición de fuerzas encontradas, buscando en ello el equilibrio. Entre las piezas más antiguas de este patrón iconográfico ${ }^{24}$, destaca una ánfora ática de cuello, fechable en torno al 540-530 a.C. ${ }^{25}$, cuya decoración muestra la lucha, cuerpo a cuerpo, entre Posidón y Polibotes, un tema llamado a tener larga vida en la cerámica griega. El dios marino sostiene en alto una enorme roca (el islote de Nísiros) con una de sus manos, mientras ataca a su rival con el tridente. En claro ademán de

\footnotetext{
${ }^{22}$ M.B. MOORE, «Lydos and the Gigantomachy», American Journal of Archaeology, Vol. 83, n. 1, 1979, pp. 79-99.

${ }^{23}$ Acrópolis 607.

${ }^{24}$ Este modelo iconográfico habría de generalizarse en los talleres áticos a partir del 520 a.C.

${ }^{25}$ Louvre F226. http://www.mlahanas.de/Greeks/ Mythology/PoseidonAndPolybotes\%20LouvreF226.html.
} 
huída, el gigante hinca su rodilla en el suelo, según el conocido procedimiento arcaico de la llamada "carrera de rodilla" y protege su cuerpo con un gran escudo de tipo beocio.

A juzgar por el elevado número de representaciones pictóricas que han llegado hasta nosotros, el enfrentamiento más célebre fue el habido entre Atenea y Encélado, asunto muy repetido en los vasos arcaicos, a partir del 520 a.C. En nuestra opinión, su difusión podría relacionarse con la supremacía de Atenas y de su diosa tutelar sobre otras poleis. Con ligeras variantes, el patrón iconográfico resulta canónico, mostrando a la diosa completamente armada y protegido su pecho con la égida, en actitud de ataque; su oponente (desnudo o ataviado como hoplita) está a punto de sucumbir por las heridas, tal y como vemos, por ejemplo, en el fondo de un plato ático del Museo del Louvre o en una ánfora procedente de Vulci, hoy en el Museo de Antigüedades del Estado de Munich (fig.2) ${ }^{26}$. Otros ejemplos muestran diversos episodios como el enfrentamiento habido entre Dioniso y Éuritos que muestra un Kyathos ático de figuras rojas del Pintor de Oinophile (Museo de Berlín ${ }^{27}$ ) en una imagen en la que las sierpes aparecen ya asociadas al gigante ${ }^{28}$.

Motivo decorativo de estos vasos de elite, la Gigantomaquia se hacía eco de las

${ }^{26}$ Inv: 1612; BEAZLEY, Beazley Archive , ABV 484, 7.

${ }^{27}$ Antikenmuseen, Berlín, F2321.

${ }^{28}$ La serpiente es un animal ctónico, unido a la Tierra a la que encarna. Hijos de Gea, los Gigantes, fueron concebidos en la iconografía como seres asociados a los ofidios, expresión del poder telúrico terrestre y en muchos casos incorporaron a su fisonomía algunos rasgos propios de éstos (escamas, cabezas de serpiente) o se representan a su lado. Sobre la iconografía de la serpiente como animal ctónico Véase D. RODRÍGUEZ PÉREZ, Serpientes, dioses y héroes. El combate contra el monstruo en el arte y la literatura griega antigua, León, 2008 y D. RODRÍGUEZ PÉREZ, «El combate contra la serpiente: el triunfo de la tierra velado bajo la aparente muerte del ofidio», De Arte, 5, 2006, pp.5-14. ideas predominantes y las trasladaba al ámbito doméstico e íntimo. Sin embargo, en ocasiones, el asunto que nos ocupa fue utilizado para la decoración de vasos de naturaleza funeraria, los lekythoi, siendo en estos casos su lectura e interpretación bien distinta, asociada a la inevitable adversidad del destino humano. Como cualquier otra batalla, la Gigantomaquia se relacionaba con la la muerte, por lo que su presencia resultaba decorosa para el ornato de vasos de uso funerario.

\section{GRECIA CLÁSICA}

Es sabido que tras la destrucción de la Acrópolis ateniense en el transcurso de las Guerras Médicas, Pericles emprendió un programa propagandístico que incluía la reconstrucción de los monumentos más emblemáticos de la ciudad ${ }^{29}$. Dentro de este proyecto ideológico se construyó, entre el 447 y el 432 a.C., el Partenón, sobre los cimientos del pre-partenón de época Pisistrátida. El programa iconográfico del edificio fue concebido para ensalzar la gloria de Atenas y exhibía, exteriormente, imágenes propagandísticas de la ciudad: el nacimiento de su diosa titular (frontón oriental) la disputa de ésta y Posidón (frontón occidental), la celebración de las Grandes Panateneas (friso) y diversas maquías o luchas célebres de la mitología: Centauromaquia (lado sur), Amazonomaquia (lado oeste), Iliupersis (lado norte) y Gigantomaquia (lado este) ${ }^{30}$, escenas susceptibles de lectura política destinadas a glorificar la supremacía ateniense, mediante el triunfo de la inteligencia sobre las fuerzas brutales y salvajes.

${ }^{29}$ J. M. BARringer, J. M. HuRWit, J.J. POllitT, Periklean Athens and its legacy: problems and perspectives, Austin, 2005.

${ }^{30}$ Estudios monográficos del conjunto puede encontrarse en I. JENKINS, The Parthenon Sculptures, Harvard, 2007; J. BOARDMAN; D FINN, The Parthenon and its sculptures, Londres, 1985. 
Quedan pocos restos de las metopas orientales del Partenón, que nos son conocidos mayoritariamente en virtud de diversas propuestas de reconstrucción; el marco arquitectónico de formato cuadrangular impuso a los escultores la representación de escenas aisladas, que muestran a los dos combatientes en plena lucha: los gigantes se han despojado de sus antiguas armaduras y aparecen como seres de fisonomía humana, desnudos, en actitud de defenderse frente a sus adversarios con grandes escudos redondos y espadas; los dioses, por su parte, lucen indumentarias diversas (vestidos o semidesnudos) y muestran ademanes dinámicos y beligerantes. Algunos de ellos aparecen montados en un carro tirado por una pareja de corceles, bajo el que yacen vencidos algunos de sus salvajes oponentes $^{31}$.

Las "Grandes Panateneas", eran las fiestas celebradas en Atenas para conmemorar el nacimiento de Atenea cada cuatro años y su institucionalización se atribuye tradicionalmente a Teseo. Tres de cada cuatro años tenían lugar el 28 y 29 del mes hecatombeo (julio) y se denominaban panateneas menores, pero, a partir del arcontado de Hipóclides (566-5 a.C.), la celebración tenía lugar cada cuatro años y revestía particular esplendor, desde el 21 al 28 de hecatombeo, recibiendo desde este momento el nombre de "Grandes Panateneas". Estas dilatadas fiestas incluían juegos, carreras hípicas y certámenes musicales, a los que los Pisistrátidas sumaron recitales poéticos. Pericles prolongó los certámenes musicales y construyó para ellos un teatro especial, el Odeón. Como es sabido, los premios de las pruebas atléticas consistían en preciados

31 K.A. SCHWAB, «Parthenon East Metope XI: Herakles and the Gigantomachy», American Journal of Archaeology, Vol. 100, n. 1,1996, pp. 81-90; K.A. SCHWAB, "Celebrations of Victoria: The Metopes of Parthenon», en J:NeILS, The Parthenon: From Antiquity to the Present, Cambridge, 2005. vasos, las llamadas ánforas panatenaicas, que se otorgaban llenos de aceite de oliva, como trofeo más importante de los certámenes $^{32}$. La fiesta culminaba el último día con una fastuosa procesión que se desarrollaba a lo largo de la Vía Panatenaica y llegaba hasta el Partenón, donde se ofrecía un peplo a la estatua de Atenea ${ }^{33}$. Este peplo había sido tejido por las doncellas atenienses con bordados que representaban la lucha entre Atenea y los gigantes; constituía un honor para una muchacha el que se la considerase 'digna del peplo'. Éste era transportado en una gran nave sobre ruedas, a la cual seguían doncellas, conocidas como arrephoroi, que portaban en cestas los utensilios necesarios para el sacrificio, grupos de mozos cargados con cántaros y de viejos con ramas de olivo, carruajes $y$, finalmente, una comitiva de jóvenes jinetes (tal como se reproduce en el friso del Partenón). La fiesta culminaba con una hecatombe, cuya carne era distribuida entre el pueblo. En el siglo V a.C., las Panateneas tenían un carácter, no sólo cívico, sino también político, celebrándose en honor de la diosa, que no era únicamente patrona de la ciudad, sino de toda la Liga Délica; la parte

\footnotetext{
${ }^{32}$ Las ánforas panatenaicas son recipientes de gran tamaño y forma característica (cuya decoración responde siempre al mismo patrón icónico: en una de sus caras se representaba a Atenea Promachos situada entre dos columnas coronadas por gallos, mientras que en la cara opuesta una escena gimnástica aludía a la circunstancia gracias a la cual se obtenía el premio. Constituyen un importante documento de filiación arqueológica, ya que muchos de estos recipientes incluían una inscripción con el nombre del arconte en funciones.

${ }^{33}$ M.E. DE LA NUEZ PÉREZ, «Las Panateneas: topografía de una fiesta», Gerión, Vol. 22, n. 1, 2004, pp. 101-120; M. VALDÉS GUÍA «El "nacimiento" de Erictonio y las panateneas: la creación de un mito» Ilu. Revista de ciencias de las religiones. Anejos n. 23, 2008 (Ejemplar monográfico sobre "El nacimiento de la autoctonía ateniense: cultos, mitos cívicos y sociedad de la Atenas del s.VI a.C."), pp. 105-152.
} 
correspondiente a cada aliado en los sacrificios estaba regulada por decretos ${ }^{34}$.

El sagrado peplo ofrendado a la diosa tutelar de la ciudad estaba bordado, no por casualidad, con escenas de la Gigantomaquia; el acontecimiento mítico, al igual que la pintura del interior del escudo de la estatua de Atenea Parthenos, traía a la memoria de los atenienses sus ideales cívicos. Plinio, en su Historia Natural ${ }^{35}$ describe el escudo de la estatua, donde se plasmaba, con todo fragor, el ataque al cielo de los hijos de Gea y la airada respuesta de los olímpicos $^{36}$. El culto de Atenea, diosa de la guerra y diosa de la inteligencia, divinidad de la prudencia y del raciocinio estuvo indisolublemente unido, como demuestran tanto los templos a ella dedicados como los rituales folklóricos en su honor, con esa idea de la defensa del orden cívico, microcosmos en el que se proyectaba el orden universal conseguido tras la victoria de los olímpicos sobre las fuerzas titánicas.

Durante la primera mitad del siglo V a.C., los pintores de vasos continuaron incorporando en sus obras diversos episodios de la contienda, tratados ahora con toda sobriedad y sencillez, buscando el equilibrio de masas y vacíos tan característico del estilo clásico. Ejemplo canónico de la iconografía de este período es un pélice ático (Louvre G434) en el que Dioniso armado con su tirso y coronado de pámpanos, somete (pisoteándole) a un gigante que trata de resistirse frente a su adversario (fig. 3). Resulta interesante señalar la presencia de una sierpe que se enrosca en una de las piernas del salvaje, animal ctónico, que como ya hemos señalado, está asociado a la

${ }^{34}$ M.C. HowATSON, Diccionario de la literatura clásica, Barcelona, 1991.

${ }^{35}$ PLINIO, Historia Natural, XXXVI, 5,4.

${ }^{36}$ VON SALIS, «Die Gigantomachie am Schilde der Athena Parthenos», Jahrbuch des Deutschen Archäologischen Instituts (JdI) 55,1940, pp. 90-169. iconografía de los gigantes. Muy significativa resulta, asimismo, la consecución de los escorzos y la tridimensionalidad espacial, así como el equilibrio compositivo que produce el vacío generado entre las figuras y las posturas complementarias y al mismo tiempo antagónicas de éstas.

El mismo equilibrio de masas y compensación de fuerzas plásticas se percibe en el fondo de un Kylix firmado por Erginos (ceramista) y Aristófanes (pintor) (Berlín, Antiken Museen) ${ }^{37}$, fechado en el último decenio del siglo $\mathrm{V}$ a.C. La presencia de Gea emergiendo de su elemento, en actitud de suplicar clemencia para su hijo, no impide que un Posidón victorioso (completamente desnudo y coronado de laurel) hunda su tridente en la coraza (un linothorax clásico) de Polibotes (fig.4). El exterior de la citada copa está decorado con una Gigantomaquia de friso continuo, en la que participan seis olímpicos frente a sus correspondientes rivales: en un lado combaten Zeus y Porfirión, Atenea y Encélado y Hécate y Clitio, mientras en el lado opuesto rivalizan Ares contra Mimón, Apolo con Efialtes y Hera con Foitos. Las diosas visten peplo de fino plegado, los dioses están desnudos y los gigantes (a excepción de Polibotes, cuya indumentaria ya se ha comentado) están desnudos, pero armados con piedras, yelmos, espadas y grandes escudos circulares. Su naturaleza ctónica queda evidenciada por la serpiente que se enrosca entre las piernas de Clitio, el rival de Hécate.

En los últimos años del siglo $\mathrm{V}$ a.C. se produjo un cambio en la iconografía de los vasos pintados. Desde este momento, los pintores plasman la batalla situando a las figuras en dos planos bien diferenciados, en ocasiones separados por un $\operatorname{arco}^{38}$. Creemos que esta innovación en la disposi-

${ }^{37}$ Berlín F2531; Beazley Archive n. 220533.

${ }^{38}$ C. Delgado Linacero, Op. Cit., 1999, p. 120. 
ción de las figuras pudo estar motivada por la ordenación de las mismas en el escudo de Atenea Parthenos, donde los personajes estarían colocados en dos planos distintos (el centro del escudo ocupado por los gigantes y el borde exterior por los dioses). Dominadores de la perspectiva, los pintores describen el asalto al Olimpo, desde abajo, de tal suerte que las figuras se representan de sotto in su, y en sus violentos ademanes se plasman difíciles escorzos, verdadera muestra de la maestría alcanzada por la pintura de aquel tiempo. Ejemplos significativos de este esquema iconográfico son, entre otros, una cratera firmada por el pintor de Syleus (Museo de Historia del Arte, Viena), una cratera del Museo Nacional de Nápoles, una ánfora procedente de Melos (Louvre S1677), un pélice del Pintor de Pronomos (Museo Nacional de Atenas, inv.1333) y una cratera apulia del Museo del Ermitage. En dichas obras los gigantes aparecen desnudos o ataviados con pieles de animales para subrayar así su naturaleza brutal y salvaje.

La Magna Grecia fue el escenario donde, al iniciarse el siglo IV a.C. surgía la iconografía del gigante como ser anguípedo provisto de extremidades inferiores serpentiformes, imagen derivada, probablemente de un sincretismo con Tifón, un ser ctónico que encarnaba a las fuerzas volcánicas ${ }^{39}$. En la nueva apariencia de los gigantes puede apreciarse la influencia de la pintura etrusca, donde el monstruoso vástago de Gea, arrojado al Tártaro o al Etna -según versiones- por Zeus, fue un motivo muy popular. Este prototipo iconográfico, como veremos, alcanzaría su máxima expresión en el arte helenístico, de donde pasaría al arte romano imperial y quedaría unido, ya para siempre, a la imagen de los Gigantes en la

\footnotetext{
${ }^{39}$ D. RODRÍGUEZ PÉREZ, Op.Cit. 2006, p. 7 y ss.
}

tradición occidental ${ }^{40}$. Entre los ejemplos más tempranos de esta iconografía de extremidad bífida y serpentiforme destacamos un lécito aribalístico atribuido al pintor de Capua, del tercer cuarto del siglo IV a.C. (París, Museo del Louvre) ${ }^{41}$.

\section{GRECIA HELENÍSTICA}

Es bien sabido que los reinos helenísticos surgidos tras la muerte de Alejandro favorecieron el desarrollo del arte, multiplicándose los centros artísticos en los que se mezcló la tradición puramente griega con las influencias de los pueblos orientales, según fórmulas muy variadas y diversas; se fomentaba así en las ciudades un ambiente culto y cosmopolita. Este período se vislumbra como una era apasionante, marcada por la crisis y el cambio: nuevas organizaciones políticas, nuevos contactos culturales y nuevas oportunidades económicas. En este marco, los intercambios ideológicos fueron determinantes, de tal suerte que los artistas reinterpretaron las ideas religiosas y los asuntos mitológicos en términos personales. Sin embargo, los repertorios iconográficos heredados de la tradición clásica siguieron en vigor como huellas de un pasado glorioso, al que era casi obligado emular.

Sintiéndose continuadores de tan ilustre pasado, los Atálidas llevaron a cabo una política imperialista, especialmente desde el reinado de Atalo I (241-197 a.C.), que conquistó a las tribus de bárbaros establecidos en Tracia y obtuvo el control sobre todos los territorios del Imperio Seleúcida situados al norte de los Montes Tauro,

\footnotetext{
${ }^{40}$ La iconografía de los anguípedos penetró en Grecia en el siglo VII a.C., procedente del mundo oriental. Los seres híbridos conformados como humanos de extremidades inferiores pisciformes sirvieron como medio icónico para la representación de Tifón y de varios seres marinos, especialmente Nereo, los tritones y los ictiocentauros.

${ }^{41}$ Louvre K509.
} 
según nos informa Polibio ${ }^{42}$. Con su sucesor, Eumenes II (197-159 a.C.), el reino de los Atálidas alcanzó la cúspide de su poder, convertido en el más fuerte de los estados de Asia Menor, después de hacerse con los territorios de Frigia, Lidia y Panfilia. Para conmemorar uno de los acontecimientos militares más importantes de su reinado, su victoria definitiva sobre los gálatas de Tracia, Eumenes II mandó levantar un colosal altar en la acrópolis de su capital, dedicado a Zeus Soter y a Atenea Nicéforos, que fue construido entre el 164 y el 156 a. $C^{43}$.

El programa iconográfico que se desarrolla en los relieves externos del conjunto (reconstruidos hoy en el Museo de Pérgamo, en Berlín) es una magnífica Gigantomaquia, la más impresionante de las que se conocen; su finalidad no fue otra que ensalzar las victoriosas gestas de la monarquía atálida, identificada simbólicamente con la genealogía de los olímpicos, frente a sus adversarios bárbaros, encarnados en las figuras de los gigantes ${ }^{44}$. La imagen artística prestaba a la monarquía pergamena un marco propagandístico incomparable, del mismo modo que lo hiciera, siglos atrás, cuando Pericles desarrolló su vasto programa de reformas en Atenas.

En este marco de prestigio y representación, los relieves que componen la Gigantomaquia de Pérgamo obedecen a una disposición jerárquica, coligada a la ordenación misma del Cosmos: los Olímpi-

\footnotetext{
${ }^{42}$ POLIBIO, Historia, IV, 48.

${ }^{43}$ E. V HANSEN, The Attalids of Pergamon, Nueva York-Londres, 1971; E. KosmETATOU, «The Attalids of Pergamon», en A Companion to the Hellenistic World, Oxford, 2003. pp. 159-174.

${ }^{44}$ D THIMME, «The Master of the Pergamon Gigantomachy», American Journal of Archaeology, Vol. 50, n. 3 1946, pp. 345-357; E.M SMITH, The Great Altar of Pergamum, Leipzig, 1962; C. DELGADO LINACERO, «El grandioso altar de Pérgamo: emblemática obra del mundo helenístico», Cuadernos de Filología Clásica, vol.12, 2002, pp. 329-344.
}

cos, encabezados por Zeus y Atenea (acompañados de Heracles) se sitúan en el friso oriental, mientras que el lado norte está habitado por los dioses de las sombras y de las aguas; y en el lado sur se disponen los dioses de la luz y de la tierra. El discurso iconográfico se desarrolla en un friso continuo donde los dioses luchan con fogosa energía para reducir a sus poderosos rivales, mostrando un repertorio de inigualable variedad compositiva y elevadísima calidad artística. Aunque dominados por el dinamismo que impone la batalla, los dioses están inspirados en prototipos clasicistas y son figuras de belleza sobrehumana que muestran infinidad de actitudes y posturas, así como una notable diversidad en sus atributos e indumentaria.

Los Gigantes, sin embargo, obedecen a postulados estéticos bien diferentes, como paradigmas del más apasionado barroco helenístico (fig.5). Sus musculosos cuerpos se retuercen en inverosímiles posturas que llegan hasta el delirio y sus rostros ofrecen un muestrario del más intenso pathos. Son figuras dolientes cuya apariencia es muy heterogénea: algunos gozan todavía de la juventud, como Alcioneo (que lucha con Atenea, mientras su madre implora la clemencia de la diosa), Oto (el rival de Ártemis), o el poderoso espécimen que sucumbe ante la llamada "diosa del león" (fig.6). Otras figuras son, en cambio, de avanzada edad. Pero todos son seres plenos de fuer$\mathrm{za}$, dotados de hermosa y abundante cabellera; unos alados, otros con extremidades inferiores serpentiformes, algunos con garras de león o escamas, cuernos de toro y otros rasgos animales que desvelan su potencia primigenia.

Los grupos de oponentes se disponen en composiciones muy complejas, definidas por el cruce de diagonales y el retorcimiento de los cuerpos, que llega al paroxismo. La posición de los dioses es siempre eleva$\mathrm{da}$, y su gesto airoso, para indicar su victo- 
ria; en cambio, los hijos de Gea están, en muchos casos, semitendidos, unidos a la tierra, ya a punto de sucumbir ante el poder divino. Tanto el tratamiento de los plegados de las indumentarias de los dioses, de surcos profundos, como la palpitante musculatura de las figuras (muy particularmente la de los gigantes), ofrecen un repertorio técnico extraordinario con el que los escultores pergamenos exhibieron lo mejor de su arte. El claroscuro y el movimiento, protagonistas de la batalla, son procedimientos efectivos para expresar el pathos, bien perceptibles en cabellos, anatomías, indumentarias, actitudes y composiciones. Por todas las características señaladas, el gran friso de Pérgamo con su Gigantomaquia, constituye una de las cimas estéticas del barroco helenístico, y la mejor expresión simbólica del poder de los reyes atálidas frente a sus enemigos. En Priene (Asia Menor), el tema que ornaba los casetones del techo del templo de Atenea Polias, fue también la Gigantomaquia, acaso porque simbólicamente expresaba la afinidad de los habitantes de Priene con Atenas, ciudad que se consideró siempre su sagrado modelo ${ }^{45}$. En torno al 150 a.C. se edificó en dicha ciudad un altar dedicado a Atenea, que estuvo notablemente influenciado por el modelo pergameno. En sus relieves se representó, asimismo, una Gigantomaquia, pero a diferencia de Pérgamo, el asunto no se desarrolló como un friso continuo, sino ocupando las metopas del conjunto ${ }^{46}$.

Así mismo, en las llamadas artes menores, el asunto que nos ocupa fue motivo recreado ampliamente por los artistas helenísticos. Entre los más sobresalientes ejemplos de ello, destaca un camafeo de la Colección Orsini, hoy en el Museo Nacional

\footnotetext{
${ }^{45}$ I. JENKINS, Op. Cit. 2006, cap 10, p. 244.

46 J.C. CARTER, The sculpture of the Sanctuary of Athena Polias at Priene, Londres, 1984.
}

de Nápoles ${ }^{47}$ (fig.7). Verdadera obra maestra en su género, y firmado por un tal Athenion, la joya muestra a Júpiter montado en una cuadriga de rápidos corceles, empuñando en la mano los atributos de poder que le identifican: el cetro y el rayo. En el suelo yace un gigante, mientras que otro, todavía en pie, trata de oponer resistencia al tonante. Los gigantes son seres de poderosa musculatura y poseen las extremidades inferiores escamosas, rematadas en prótomos de serpiente. El prototipo de Zeus es, asimismo, el distintivo del período helenístico, con abundante barba y cabellera ondulada, extraordinaria musculatura y rostro expresivo.

\section{ETRURIA}

La influencia de la iconografía de la cerámica griega, tan admirada por los etruscos, penetró pronto en el ámbito tirreno. Los obradores locales reinterpretaron asuntos y patrones llegados de la Hélade, especialmente los modelos áticos; y lo hicieron de acuerdo con su particular visión estética. El tema de la Gigantomaquia irrumpió en los vasos pintados etruscos a finales del siglo VI a.C. con un tratamiento inusual y ecléctico. Así lo demuestra una ánfora de figuras negras (Walker Art Center, Minnesota), obra donde la reinterpretación del modelo resulta ser una combinación peculiar y poco ortodoxa de los patrones áticos. Heracles y Atenea se enfrentan a dos rivales armados con enormes piedras, dentro de un espacio marcado por el innato decorativismo propio del arte etrusco ${ }^{48}$. Creemos que el eclecticismo y la desacostumbrada forma de tratar el tema se debe a que éste carecía de sentido profundo en Etruria, donde había pasado a ser un moti-

\footnotetext{
${ }^{47}$ Inv. 25848. S. DE CARO, The National Archaeological Museum of Naples, Nápoles, 1996, p. 346.

${ }^{48}$ R OLSEN CARLUCCI, «An etruscan black-figure Gigantomachy in Minneapolis», American Journal of Archaeology, Vol. 92, n. 4 ,1978, pp. 545-549. Figs. 1 y 2.
} 
vo meramente ornamental como emulación del respetado paradigma griego.

El asunto fue objeto de atención, asimismo, en las cistas y espejos de bronce, así como en las grandes terracotas de los acroteria de los templos o en las urnas cinerarias Entre las cistas, señalamos un ejemplar procedente de la antigua Praeneste (colección Loeb de Munich) cuyos grabados muestran una Gigantomaquia adaptada, también en este caso, al capricho etrusco. Fechada hacia los años centrales del siglo III a. C. ${ }^{49}$, se considera obra de los talleres prenestinos. Los interesantes diseños que cubren el campo decorativo muestran a dioses y a los gigantes, en brutal liza, alineados en un friso continuo. Se distinguen con claridad Posidón, Dioniso y Atenea que se enfrentan a cuatro gigantes. A pesar de que los modelos de inspiración fueran griegos, probablemente vasos suritálicos del siglo IV a.C., el pintor etrusco utiliza atributos iconográficos y fisonomías poco acostumbradas. Así, por ejemplo, el gigante que combate con Posidón es similar a un monstruo marino alado de extremidad bífida, un ser análogo a algunos "daimones" etrus$\cos ^{50}$ conocidos a través de los repertorios incisos de los espejos de bronce ${ }^{51}$ y ocasionalmente utilizado en Etruria para la caracterización de los Gigantes. Otros aspectos interesantes de esta contaminatio pueden encontrarse en la montura de Dioniso, un animal fantástico (un grifo y no la acostumbrada pantera), o en el hacha característica de las amazonas (la sagaris) que sostiene uno de los gigantes en su mano, así como en las indumentarias orientales de algunas figuras, que lucen capa y gorros frigios. Entre las armas de los gigantes, además de

${ }^{49}$ G.H. CHASE, «A Praenestine cista in the Collection of James Loeb. Esq.», American Journal of Archaeology, vol.15, 1911, pp. 465-481.

${ }^{50}$ M.I. RODRÍGUEZ LÓPEZ, «Dioses y demonios marinos en el mundo etrusco», Akros, n. 5, 2006, pp. 61-70.

${ }^{51}$ E. GERHARD, Etruskische Spiegel, IV [1973], 286, 1. la citada hacha, se cuentan las consabidas ramas de árboles y piedras.

Para finalizar esta breve incursión en el arte de los etruscos, baste la sola mención de una urna cineraria de Perugia (Museo Arqueológico de Perugia), de época helenística $^{52}$. Según el esquema habitual de estas piezas, la difunta recostada ocupa la tapa del receptáculo en cuyo frente, como si de un pequeño sarcófago se tratara, se dispone una escueta Gigantomaquia. En los relieves se advierte la presencia de Zeus tonante aplastando a un rival y la de Hércules, en actitud de empuñar su clava contra otro adversario (de extremidad serpentiforme y bífida) que está a punto de lanzarle una piedra. Las escenas de batalla fueron el tema predilecto para adornar los relieves de las urnas cinerarias de época helenística, siendo la Amazonomaquia otro de los esquemas míticos de lucha más recurrentes. La batalla implica y sugiere la muerte, por lo que el motivo resultaba muy apropiado al ámbito funerario.

\section{ARTE ROMANO.}

El tema que nos ocupa continuó siendo un motivo de representación plástica cargado de simbolismo propagandístico en el arte romano. En los tiempos de la República no fue, como es lógico, muy difundido y aunque determinadas acuñaciones monetales de las familias Cornelia y Valeria se hicieron eco del antiguo mito, habría que esperar a que la ciudad de Roma se convirtiera el centro de un gran Imperio para que estos iconos parlantes fueran utilizados como formas de expresión del poder. La iconografía de los gigantes y las Gigantomaquias recobraron su actualidad en época de los Antoninos, tanto en las monedas como en la escultura.

\footnotetext{
52 http://www.flickr.com/photos/dandiffendale/23 $67618244 /$
} 
Sin embargo, desde época temprana comenzaron a erigirse en Germania Superior, monumentos conmemorativos de las victorias de Roma, que se generalizaron en todo el ámbito germánico, durante los siglos II y III de la Era. Las columnas votivas, conocidas como Jupitergigantensäulen o Jupitersäulen, son documentos pétreos que expresan la relación existente entre las victorias militares y los dioses romanos. Dado que se trata de símbolos propagandísticos del poder imperial, la estructura de dichos trofeos responde a un esquema tipificado: sobre un pedestal cúbico decorado con relieves de dioses dadores de la Paz (Juno, Minerva, Mercurio y Hércules) se yergue el fuste de la columna, a veces decorado con escenas figurativas o con motivos vegetales y en ocasiones liso, que se corona con una figura de Júpiter. El dios, representado como jinete (acaso por sincretismo con el dios germano Wodan), aparece en actitud de derribar a un gigante, habitualmente representado con extremidades serpentiformes (fig. 8$)^{53}$.

La Gigantomaquia procedente de Afrodisias (Lidia, Asia Menor),de época imperial (Museo Arqueológico de Estambul) sigue de cerca el modelo pergameno en cuanto a la iconografía, aunque es muy inferior a éste en lo que a la calidad artística se refiere, por su carácter academicista (fig.9). Los relieves de esta batalla fueron hallados en las proximidades de la puerta del ágora de la ciudad y son similares a un friso con representación de la Amazonomaquia que se encontró a su lado. Algunos de los gigantes llevan piedras en sus manos, armas arrojadizas con las que atacan a sus enemigos, según modelos iconográficos arcaicos y clásicos.

53 P.N. BAUChHENB, Die Jupitersaülen in den germanischen Provinzen, Colonia, 1981.
En los bustos-retratos de época imperial, especialmente en la época de Marco Aurelio $^{54}$ y Comodo, las figuras de los gigantes sirvieron como ornamento de naturaleza alegórica en la coraza que visten los emperadores. De esta suerte, el retrato imperial romano quedaba convertido en alegoría política, que lleva implícita la fuerza del retratado, equiparado con el dios vencedor $^{55}$. El tema reaparece, asimismo, en los relieves que ornan la base de una columna del templo del foro severiano de Leptis $M \operatorname{sgna}^{56}$, en Libia, y se prolonga hasta los últimos siglos del Imperio, como ponen de manifiesto los mosaicos de la Villa del Casale en Piazza Armerina (Sicilia), de cronología incierta (S. III-S. V d.C.). Un mosaico polícromo, de forma absidal muestra a cinco poderosos gigantes, heridos por Heracles, que decoran el triclinio de este imponente conjunto residencial. Arrodillados en su seno, los dolientes hijos de Gea tratan de extraer de su torso las saetas que han causado sus heridas. Son figuras grandiosas, de potente musculatura y cuerpos contorsionados por el sufrimiento, que poseen extremidades inferiores bífidas rematadas en cabezas de ofidios (fig.10). En este contexto arqueológico de elite, cuya filiación no está clara, no es posible valorar el simbolismo de las figuras, aunque todo parece indicar que su inclusión pudiera obedecer a un programa iconográfico premeditadamente concebido. Algunos autores ${ }^{57}$ de-

\footnotetext{
54 http://thecorner.files.wordpress.com/2008/01/ mar cus_aurelius_bust 2.jpg.

${ }^{55}$ En ocasiones, el monstruo vencido sirve de "escudo" para su rival invicto, que lo incorpora en su caracterización como elemento apotropaico. Atenea, por ejemplo, exhibe el Gorgoneion sobre su pecho, de tal suerte que las cualidades petrificadoras del monstruo se convierten en una amenaza terrorífica para sus posibles adversarios.

${ }^{56}$ Jamahiriya Museum, Trípoli.

57 C. SFAMENI, Ville residenziali nell'Italia tardoan-
} tica, Palermo,2006; A. CARANDINI, A. RICCI, M.DE VOS, Filosofiana, La villa di Piazza Armerina: immagine di un 
fienden la lectura de un programa unitario, ideado para ensalzar la victoria del hombre sobre las pasiones y las fuerzas brutas gracias a la música. Un programa icónico que, en última instancia, alude a la supremacía de la virtud y de la felicidad sobre el desorden y las potencias del mal.

\section{PERVIVENCIAS ICONOGRÁFICAS EN LA EDAD MODERNA.}

Tras el paréntesis de la Edad Media, los artistas del Renacimiento retomaron en sus obras el tema que abordamos, casi siempre como expresión de mensajes propagandísticos. El asalto al Olimpo y la consiguiente derrota de los gigantes volvió a ser objeto de atención en las artes plásticas, muy particularmente entre pintores y grabadores, buenos conocedores de las Metamorfosis de Ovidio que alcanzaron en aquel tiempo amplia difusión.

Las representaciones de este período refuerzan la antigua idea de los pintores griegos y disponen a los rivales en dos planos bien diferenciados, de tal manera que los olímpicos siempre ocupan su lugar en las alturas, mientras que los gigantes atacan la divina morada desde la tierra, armados con piedras. La iconografía muestra, por lo general, dos momentos: el ataque al Olimpo y la caída de los gigantes. Cuando en 1527, el manierista florentino conocido como Perín del Vaga (1501-1547) entró al servicio del almirante genovés Andrea Doria, se encargó de la decoración del Palazzo Fassolo (el llamado Palacio del Príncipe o Villa Doria), en Génova. En dicha residencia, modélica para el ulterior desarrollo de la pintura palaciega local, realizó varios frescos con temas de la Antigüedad: Los Triunfos, Los Héroes, La Caída de los Gigantes y El naufragio de Eneas. La Caída de los Gigantes ocupa el techo de uno de los ambientes más

aristocratico romano al tempo di Costantino, Palermo, 1982. importantes de la citada residencia, todavía hoy en muy buen estado de conservación. En la pintura se sintetizan, de forma sinóptica, varios momentos del mito: en la parte superior Júpiter, rodeado por sus hermanos olímpicos, está representado en el momento de lanzar su rayo contra los gigantes caídos, como castigo por haber intentado asaltar el Olimpo (momento que puede apreciarse en segundo plano). Los colosos, aterrados por el fulgor del divino rayo, se acogen al seno de la tierra madre ${ }^{58}$. La composición fue grabada al aguafuerte por Faustino Anderloni (1766-1847) en los primeros años del siglo XIX, como alegoría del Triunfo de Napoleón sobre sus enemigos ${ }^{59}$.

El Palazzo Te, residencia estival de los Duques de Mantua, constituye la obra maestra de Giulio Romano (1499-1546), uno de los más acreditados discípulos de Rafael ${ }^{60}$. La Sala dei Giganti (fig.11) es un ambiente excepcional, marcado por el estilo ilusionista, extravagante y pleno de fuerza plástica tan característico del pintor. Los frescos del artista invaden por completo la estancia, tanto sus paredes como su bóveda, de tal suerte que la batalla entre dioses y gigantes, y la consiguiente caída de éstos, adquieren verosimilitud, ya que están inmersos en un espacio tridimensional, esférico y continuo, que se dilata hasta el infinito en el soberbio trompe l'oeil de la cúpula. Los artificios técnicos utilizados por el artista y el domi-

\footnotetext{
${ }^{58} \mathrm{http} / / / \mathrm{www}$. italicon.it/museo/I031-031.htm.

59 http://www.lombardiabeniculturali.it/img_db/ bcsmi/ 1q030/1/1/2_138.jpg.

60 B: GUTHMÜLLER, «Ovidübersetzungen und Mytholo-gische Malerei. Bemerkungen zur Sala dei Giganti Giulio Romanos», Mitteilungen des Kunsthistorischen Instituts in Florenz XXI, 1977, pp. 3568; K. OBERHUBER, «L'appartamento dei Giganti» in Giulio Romano, Milán, 1989; S PIERGUIDI,: «Gigantomachia and the wheel of fortune in Giulio Romano, Vincenzo Cartari and Anton Francesco Doni, and the authorship of the Asinesca Gloria», Journal of the Warburg and Courtlaud Institut (JWCI), vol. 67, 2004, pp. 275-284.
} 
nio de la perspectiva convierten el conjunto en un asombroso e insólito ejemplo de la temática de la Antigüedad.

Las imágenes parecen seguir el texto de las Metamorfosis de Ovidio ${ }^{61}$. Sentados sobre las nubes, en lo alto del espacio de la cúpula celeste (que se convierte en espacio ficticio y real al mismo tiempo), los olímpicos contemplan la caída de sus oponentes; entretanto Zeus, turbado y furioso, empuña el rayo en la diestra, provocando el pánico de sus adversarios. En el centro de la cúpula aparece el águila, símbolo del Imperio, en torno a la cual rotan las figuras de los dioses olímpicos. Con su impetuoso soplo, los cuatro vientos personificados en las pechinas, contribuyen también a turbar el ambiente y a la definitiva caída de los hijos de Gea. Las paredes de la sala, muestran cómo los descomunales gigantes se desploman en un vertiginoso descenso hacia su elemento nutricio. Un templo jónico que se derrumba en uno de los laterales de la estancia, una representación espacial convulsa que, simbólicamente, parece expresar la pérdida de la armonía inherente al Manierismo.

Los gigantes poseen hercúleas anatomías y se disponen, dolientes y expresivos, entre las rocas y los edificios caídos. Sus rostros parecen emitir gritos de inmenso dolor. Desde el punto de vista compositivo, todas las escenas tienen su nexo de unión en el río, cuyo curso se desarrolla en las cuatro paredes de la estancia, sin solución de continuidad, llevando la mirada del espectador hacia una dimensión tranquila, ajena al tremendo fragor de la "caída", tras la cual algunos de los gigantes quedan aplastados por las rocas, y definitivamente sepultados en la tierra. Este extraordinario conjunto fue pintado entre 1532 y 1535 y, según han señalado algunos autores, podría ser una alusión a la victoria de Carlos V

${ }^{61}$ OvidiO, Metamorfosis, I, 515 y ss. sobre los franceses, en memoria de la visita que el emperador (Señor de Federico II Gonzaga) había realizado a Mantua poco tiempo atrás ${ }^{62}$.

El asunto que abordamos fue muy del gusto de los manieristas italianos, ya que les permitía hacer alarde de sus conocimientos perspectivos y representar cuerpos convulsos y expresiones delirantes. Quizás por ello, el tema fue tratado en diversas ocasiones, entre las que destaca, la bóveda pintada al fresco en el Palazzo Barberan-Porto, en Vicenza, por Domenico Brusasorzi (1516-1567). Los grabados de las numerosas ediciones de las Metamorfosis de Ovidio que vieron la luz en el último cuarto del siglo XVI, presentan también el tema con los dos planos bien diferenciados: el celestial, presidido por el omnipotente Zeus, y el terrenal, donde las figuras de los gigantes levantan inmensas piedras para atacar su divino objetivo. En nuestra opinión, serían las composiciones de estos grabados las que influirían en la representación ulterior del asunto.

En torno a 1637, Guido Reni realizó un gran cuadro con el tema de la Gigantomaquia, acaso un boceto para la decoración de un techo de una residencia privada, como sugiere la acentuación forzada de la perspectiva. En esta obra, la compostura típica del maestro boloñés cede su lugar a una composición de movimientos vigorosos y de trazos violentos, destinada a evocar el encuentro mítico entre las divinidades olímpicas y los espeluznantes hijos de la tierra. Subyugados por la ira de Zeus, representado junto al águila y a su rayo fulminador, los gigantes caen entremezclados entre enormes masas pétreas.

De todas las representaciones barrocas de los gigantes y su aniquilación, la más expresiva y elocuente, a nuestro juicio, es la

\footnotetext{
${ }^{62}$ K. Oberhuber, Op. Cit. pp. 364-374.
} 
que realizara el escultor francés Garspard Marsy, para el Versalles de Luis XIV, conocida como el Estanque de Encélado (fig.12). El vencido rival de Atenea emite un doloroso lamento, mientras trata de liberar su cuerpo de la lava del Etna, donde se está anegando lentamente. Todavía tiene aliento para elevar su torso y su cabeza, rebelándose contra el cielo, mientras sostiene, con amenazadora actitud, una piedra en su mano. Resulta magistral el contraste barroco entre las texturas de la lava y la dorada figura del gigante, que simula un auténtico "tableu vivant". En el contexto de la iconografía versallesca, la caída del gigante debe entenderse como un mensaje susceptible de lectura política: la imagen del vencido enemigo ante el omnípodo poder de Luis $\mathrm{XIV}^{63}$.

Durante el siglo XVIII, también pintores y grabadores representaron ocasionalmente el asalto al Olimpo, aunque en composiciones menos magnificentes que las que les habían precedido. Francisco Bayeu repite el tema, por ejemplo, entre las alegorías referidas al Triunfo de la monarquía española en uno de los techos del Palacio Real de Madrid, en 1764. Y desde las grandes estancias pintadas al fresco, el asunto pasó también a las artes menores (con sentido puramente ornamental), siendo reproducido en porcelanas y biscuits, que dejan ver con toda nitidez el protagonismo a Zeus, cuyo sólo rayo es capaz de exterminar a todos los gigantes.

Los grandes programas iconográficos del Romanticismo, demuestran cómo la Gigantomaquia había perdido su actualidad, ya que la pintura de historia y la representación de las batallas de los hombres pasaron a suplantar a los enfrentamientos conocidos por las antiguas fábulas. Desde

\footnotetext{
${ }^{63}$ En relación con la iconografía versallesca y la imagen del poder real de Luis XIV, Véase P. BURKE, La fabricación de Luis XIV, Madrid, 1995 [1ª ed. 1992].
}

entonces, los artistas han recreado el asunto sólo en contadas ocasiones, como mera reminiscencia de un antiguo mito cosmogónico, pero exento ya de significación política, propagandística, religiosa o funeraria. Y esa carencia de significado hizo que el tema se fuera desvaneciendo paulatinamente en la memoria de los artistas, ya que había perdido su verdadera razón de ser.

\section{REFLEXIÓN FINAL}

Como hemos podido comprobar a lo largo de estas líneas, la rebelión de los gigantes y su sometimiento fueron iconos utilizados para transmitir mensajes intelectuales, en muchos casos dotados de una poderosa carga política, claramente vinculada con la soberanía ateniense. Su utilización en edificios públicos representativos, se remonta al ámbito griego del siglo VI a.C., llegando a su cenit en el arte pergameno; y desde los contextos públicos, cívicos o religiosos, pasó también la esfera de lo doméstico y lo funerario. Etruria utilizó la Gigantomaquia como tema heredado del mundo griego, pero en esta cultura las imágenes fueron sometidas a una interesante contaminatio que refleja, en la mayoría de los casos, la vacuidad de su significación. Con el imperio romano, la rebelión de los gigantes y su consiguiente caída recobraba toda su actualidad, como símbolo y alegoría del vencido, siendo Zeus (equiparado con el Cesar) el dios más prodigado en las representaciones romanas.

Los artistas de la Edad Media desatendieron el asalto al Olimpo y sus consecuencias, hasta que los frescos de los manieristas florentinos lo hicieran resurgir con vehemencia. Para éstos, la Gigantomaquia no sólo fue un medio simbólico de expresión del poder principesco, sino también un vehículo de experimentación formal muy adecuado a sus preceptos estéticos. Las convulsas figuras de los gigantes caídos sirvieron también para formular la metáfo- 
ra de la quiebra de la armonía del Universo y tal vez, la de la propia pintura. Como punto final de esta larga andadura icónica, los artistas barrocos y muy en particular los escultores, trataron el tema con gran realismo, percibiendo la intensidad del antiguo pathos helenístico o fingiendo en sus crea- ciones las texturas de la tierra volcánica que, a la postre, hubo de enterrar a sus vástagos. Allí rugen sepultadas para siempre esas bestiales fuerzas primigenias de la Naturaleza, desde que fueran borradas de la memoria de los artistas, a mediados del siglo XIX.

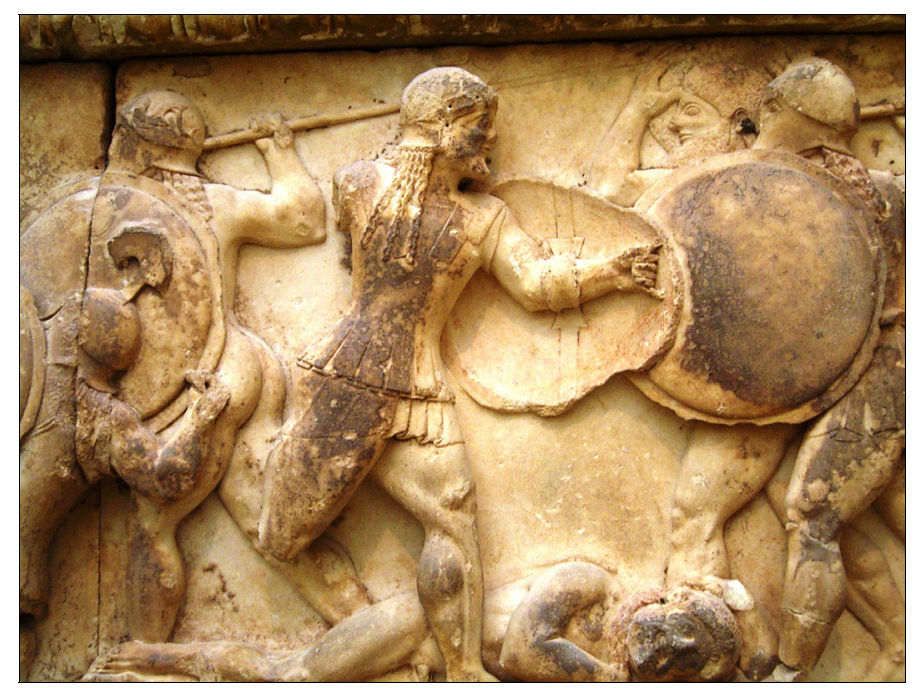

- Lám. 1. Detalle de la Gigantomaquia del Tesoro de los Sifnios. 525 a.C. Museo de Delfos. Foto de la autora (2005).

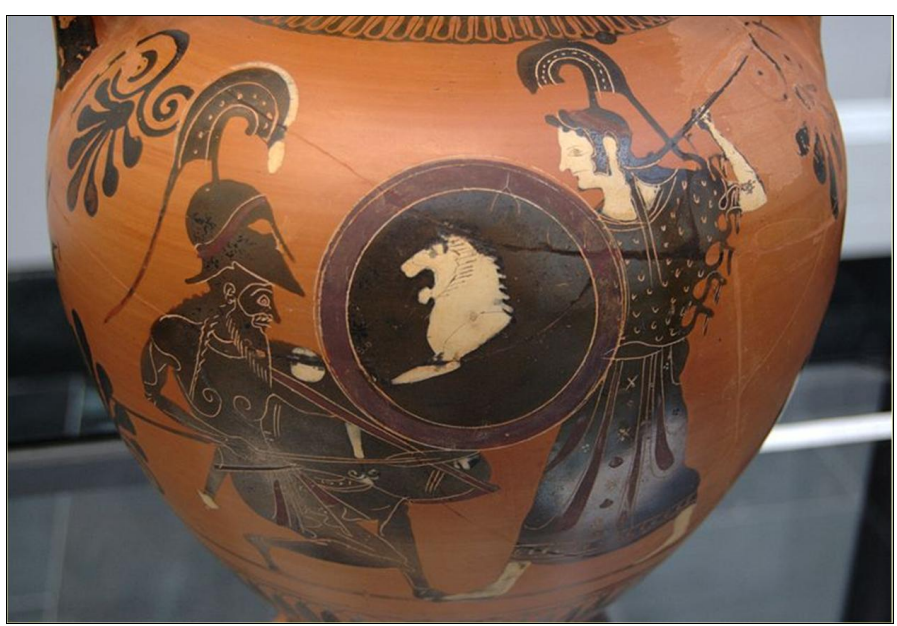

- Lám. 2. Ánfora ática. De Vulci. 520 a.C. Staatliche Antikensammlungen, Munich. (Inv: 1612; Beazley, ABV 484, 7) Foto: http://commons.wikimedia.org/wiki/File:Athena_ Enkelados_Staatliche_Antikensammlungen_1612.jpg. 


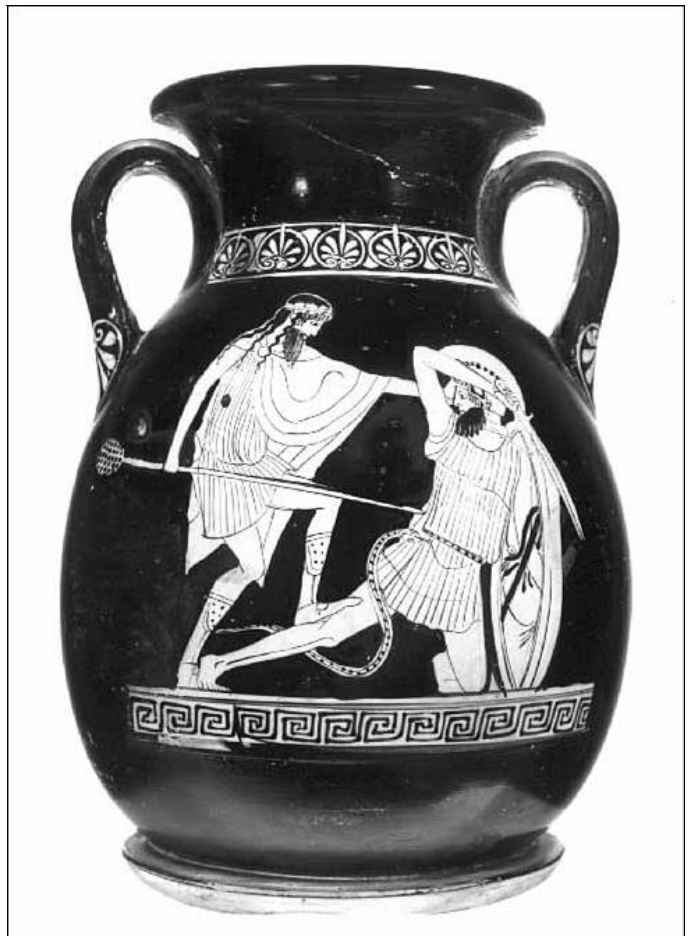

- Lám. 3. Peliké ático procedente de Nola. 460450 a.C. París, Museo del Louvre, (G 434) (C) Musée du Louvre http://cartelen.louvre.fr/ cartelen/visite?srv=car_not_frame\&idNotice= 7387.

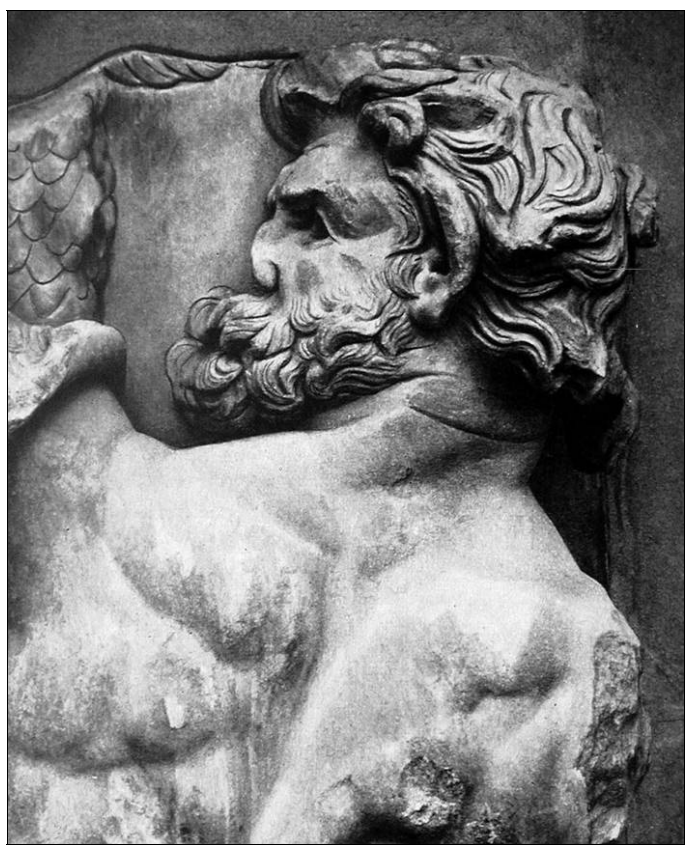

- Lám. 5. Detalle de la Gigantomaquia del friso exterior del Altar de Pérgamo. Porfirión. S. II a.C. Foto de la autora (2000).

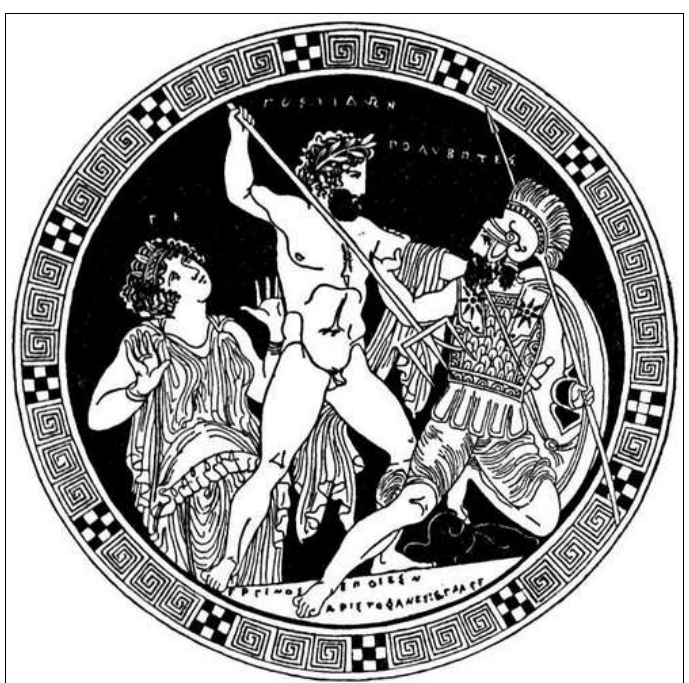

- Lám. 4. Fondo de una copa firmada por Aristófanes. ca 410 - 400 a.C. Berlín, Antikenmuseen. Foto: http://z.about.com/d/ ancienthistory/1/0/w/5/2/Poseidon.jpg. Clipart.com

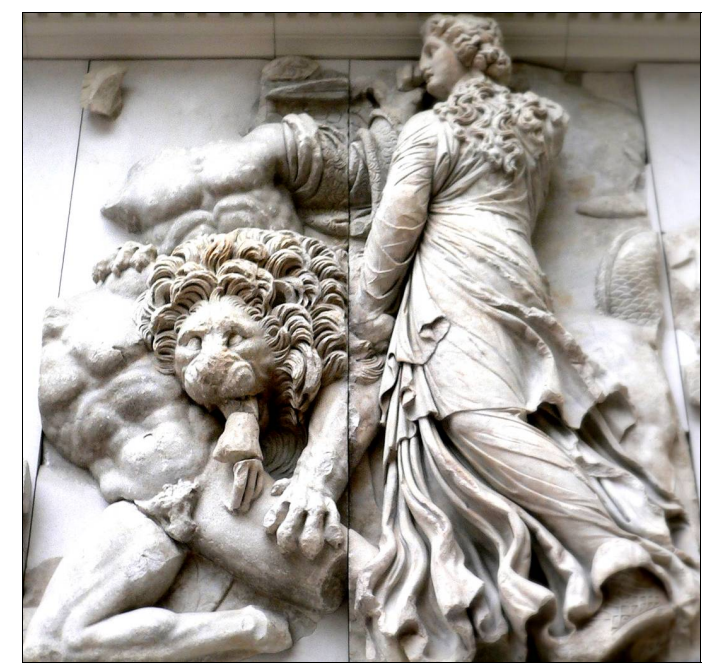

- Lám. 6. Detalle de la Gigantomaquia del friso exterior del Altar de Pérgamo. La "diosa del León”. S. II a.C. Foto de la autora (2000). 


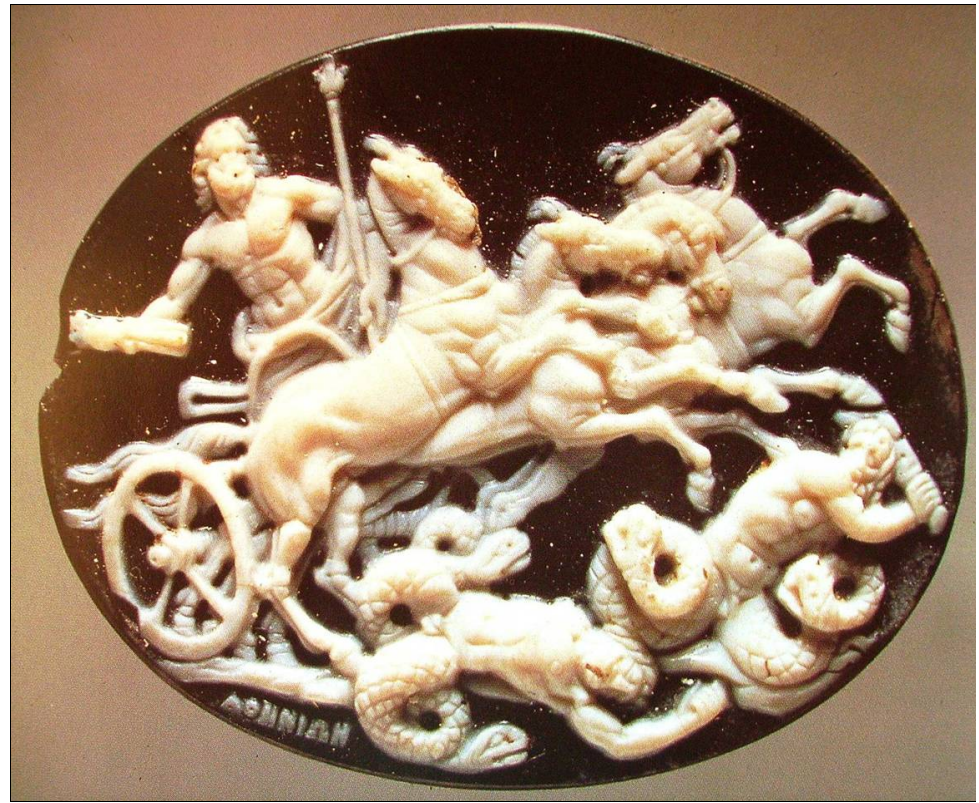

- Lám. 7. Camafeo de la Colección Orsini . Zeus abatiendo a los Gigantes. Museo Nacional de Nápoles. Firmado por Athenion. S. III-II a.C. S. DE CARO, The Nacional Archaeological Museum of Naples, Nápoles, 1996, p.346.

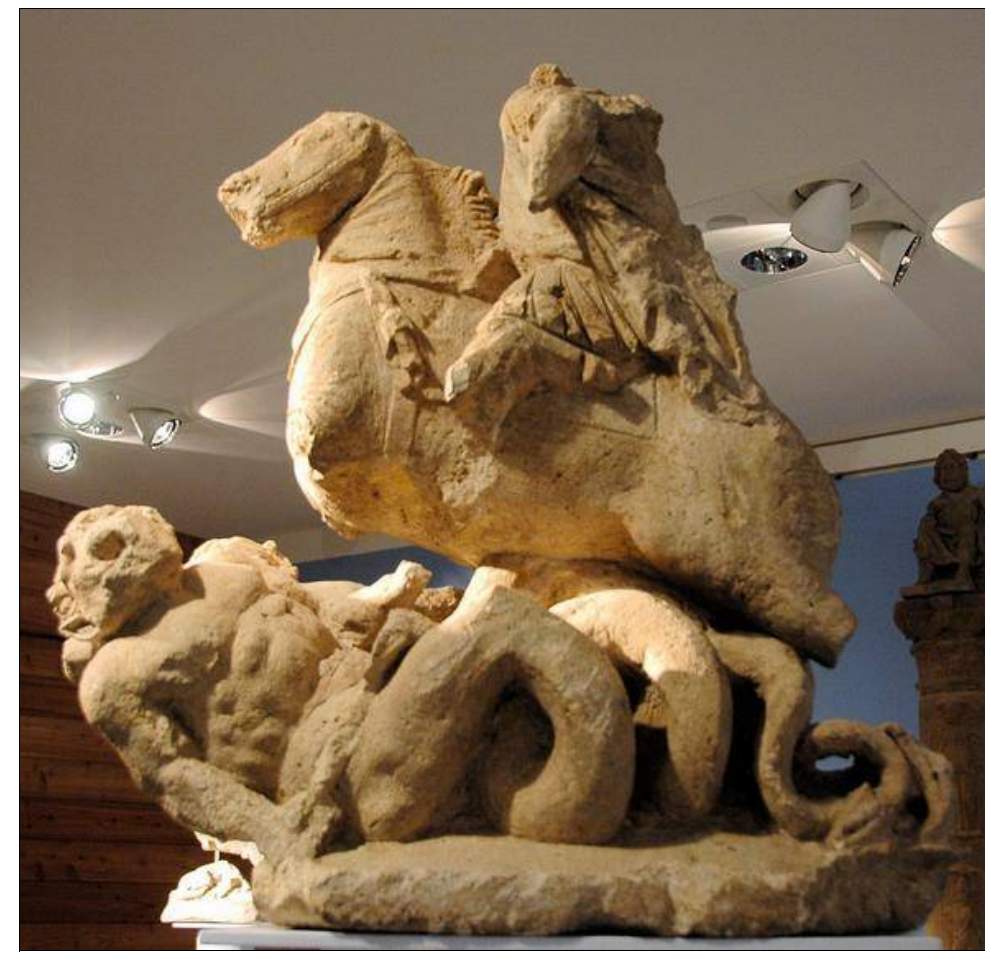

- Lám. 8. Grupo escultórico que remata una "columna de Júpiter". Tongeren, Museo Galo romano. S. I d.C. Foto: http://www.livius.org/a/belgium/tongeren/tongeren_jupitergiga ntenzuil.jpg. 


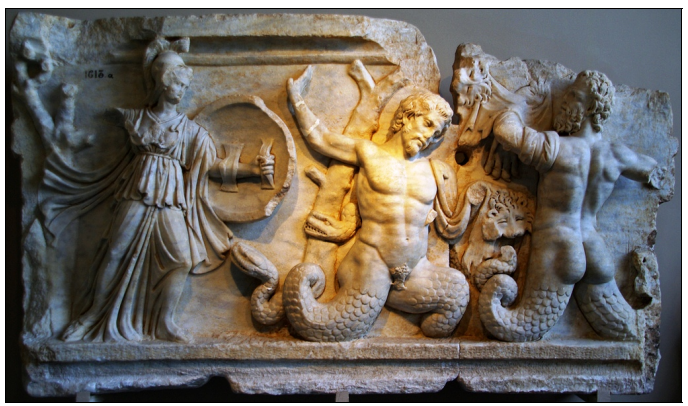

- Lám. 9. Detalle de la Gigantomaquia procedente de Afrodisias. S. II. d.C. Museo Arqueológico de Estambul. Foto: http://farm4.static.flickr.com/3215/283704637 5_c55bd39c77.jpg.

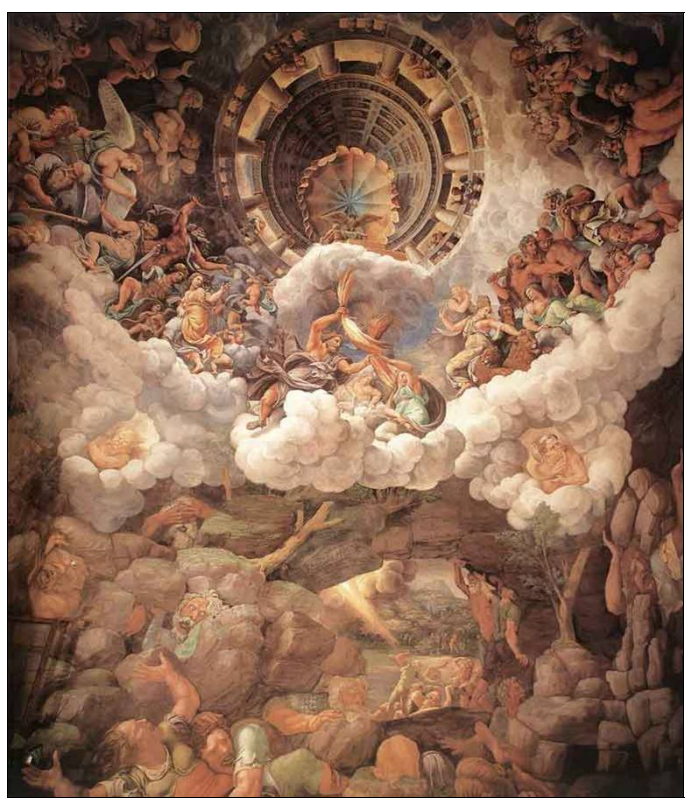

- Lám. 11. Giulio Romano. Sala dei Giganti. Mantua. Palazzo Te. Foto: http://www. mlahanas.de/Greeks/Mythology/Gigantomac hy.html.

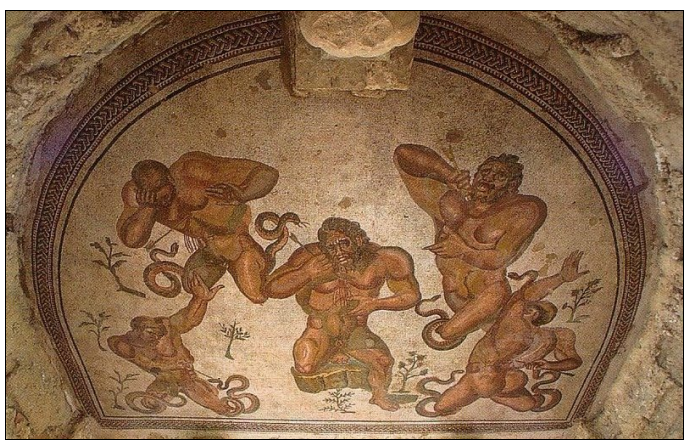

- Lám. 10. Triclinio de la Villa romana del Casale en Piazza Armerina, Sicilia. Foto: picasaweb.google.com/.../qGxVIYQj3lKHrW b6u1eOig.

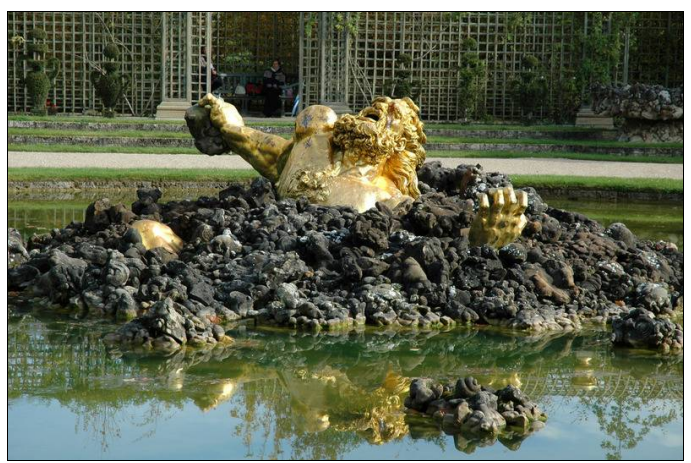

- Lám. 12. Estanque de Encélado en Versalles. Grupo escultórico de Gaspard Marsy. S. XVII. Foto: http://farm3.static.flickr.com/ 2044/ 1546156565_f8e06f78ae_o.jpg. 